\title{
UK consults public on clones for research
}

[LONDON] Two advisory groups to the British government are seeking public endorsement of research using cloned human embryos less than 14 days old, pointing out that experiments using conventionally fertilized embryos of this age are already allowed under British law.

The Human Genetics Advisory Commission (HGAC) and the Human Fertilization Embryo Authority (HFEA) also argue that a sharp distinction should be made between 'therapeutic cloning' - a category that would include such experiments - and 'human reproductive cloning', which is already effectively banned in Britain.

A consultation document published in London last week seeks public comment on both aspects of cloning. It is expected to help guide ministers in drafting legislative guidelines setting out the conditions under which experiments with 'therapeutic cloning' would be allowed.

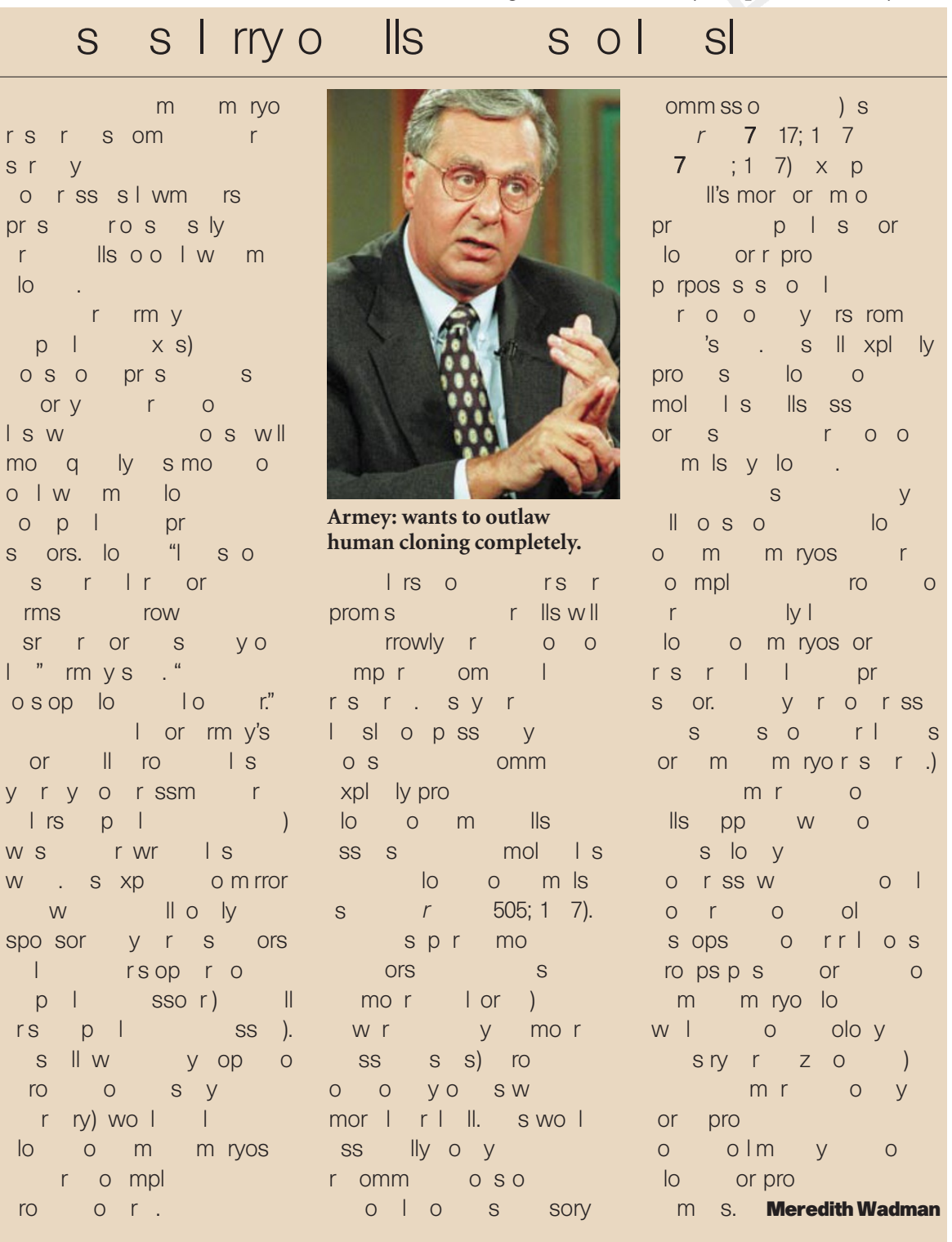

The process is being seen as parallel to that following the birth of the first 'test-tube' baby in 1978. This led to the setting up of the HFEA to police the whole area of infertility research treatment, the hub of a regulatory process described by Sir Colin Campbell, vice-chancellor of the University of Nottingham and chair of the HGAC, as "probably the finest system in the world". Campbell described reproductive cloning as "inefficient, unsafe and morally repugnant". But he warned that it would be unwise to rush into legislation that turned out to be too restrictive both on research and on new forms of infertility treatment. "We are trying to advise ministers and parliament with enormous exactitude on how to frame the regulations," he said.

The decision to produce a document for public consultation was made last year, shortly after the birth of the cloned sheep Dolly. Although the HFEA already has the right to refuse any request to carry out human cloning - and has indicated that it would do so - it was also felt important to consult on some of the wider issues involved.

In particular, the authority appears keen to head off opposition to research with potential medical applications that would involve the transfer of a nucleus from a mature human cell into an embryonic cell, which might technically be described as human cloning.

Anne McLaren, a member of the HFEA, says that no applications have yet been received for a licence to carry out such experiments, but that this situation might well arise. For example, research which might generate in vitro stem cells and cause them to differentiate into specific cell types could provide insights into inducing regeneration of damaged tissue without risk of rejection.

"We expect one day there will be an application for research under 'therapeutic cloning' which will not lead to a new baby, but might lead to medical progress," says Ruth Deech, a family law specialist who is principal of St Anne's College, Oxford, and chair of the HFEA. "We are in a transitional phase, which is why this is a good time to consult the public."

As well as asking for general views about reproductive cloning, the consultation document therefore specifically asks: "Would research using nuclear replacement technology raise any new ethical issues in relation to what is permitted in work with embryos in the 14-day period?"

Groups keen to see the general development of infertility treatments, and which back the government's current endorsement of embryo research under strictly regulated conditions, say they have no difficulties. "I would not see any ethical difference between using an uncloned embryo and a cloned one," says Juliet Tizard of the pressure group Progress.

In contrast, 'pro-life' groups, who remain opposed to all research on fertilized embryos, say they intend to raise the same arguments as were previously used - unsuccessfully — to block more conventional lines of research.

"Ontological arguments do not distinguish between ordinary embryos and embryos that have been cloned," says Peter Garrett of the group Life. "We remain on a collision course [with researchers] on this issue; we continue to argue that the totipotent embryo should not be 'denatured."

Garrett also argues that giving the green light to therapeutic cloning is likely to lead to an eventual acceptance of reproductive cloning. But Deech disagrees: "I do not think work on therapeutic cloning will make it easier to do reproductive cloning. She adds: "Our experience with embryo research demonstrates that you can take account of public feelings without getting in the way of research." 